more important than the first. If the people themselves wished to abandon or to remodel a traditional organization there was no reason why they should not do so. Further, although at one time the system of indirect rule had been viewed with suspicion by more advanced members of the community, it was now generally approved; some antagonism existed between the younger and more progressive elements and the older and more conservative, but the antagonism was less than might have been expected, and there was a real and conscious determination to avoid it. Various devices had been adopted, especially in the Western provinces, to secure the co-operation of the younger and better-educated men in the administration.

Sir Bernard then went on to discuss the share taken by Nigerians in the direction of major policy, as distinct from the partnership in administration which he had been describing. He pointed out that in a Crown Colony the direction of policy was in the hands of the Governor alone; there was no half-way house between this form of government and responsible self-government, and it was necessary to recognize that fact. There could be a gradual preparation for the change-over, but there could not be a gradual change-over. Therefore in examining the progress of partnership at this level in Nigeria the question to be considered was how far Nigerians share with the alien bureaucrats the duties of advising the Governor. The Governor was advised by his'Executive Council, his Legislative Council, and the heads of departments and other senior officers. At present in Nigeria there were no African heads of departments and not many senior African officers, but the temedy for this was only a matter of time, there being no post from which an African was excluded on account of his race. In the Legislative Council the majority of unofficial members was African, and their influence on the passage of a Bill was really important, particularly in the finance committee, which consisted of unofficial members only, except for the chief secretary and the financial secretary. It was an important fact that not one farthing of the tax-payers' money could be spent without the prior approval of a body having a large majority of African members. On the Executive Council two of the three unofficial members were Africans.

In conclusion Sir Bernard indicated that there was need for certain reforms, such as a closer connexion between native authorities and the central legislature. The time had not yet come for the Nigerian peasant to elect his own representatives to the legislature, and the present unofficial members did not sufficiently represent the peasant class. The native authorities, however, could be trusted to protect the interests of the peasants if they were represented in the legislature. He did not consider that the native authority system was incompatible with self-government at the centre; if an alien bureaucracy could govern through indigenous institutions there was no reason why a native central government should not do the same or why native authorities should not become an integral part of a representative government.

\title{
Bekwai Education Committee (Gold Coast)
}

AN instance of the enthusiasm inspired by the work of Mr. Meyerowitz, formerly Supervisor of the Art Department at Achimota and now on the staff of the new Institute of West African Arts, Industries, and Social Science, comes from the small town of Bekwai in Ashanti. In I94I the Headmaster of the local Methodist Mission school, having heard Mr. Meyerowitz outline his aims, launched a scheme to teach his pupils something of the indigenous arts and crafts. Financial support was given by a prominent European merchant who is well known in the Gold Coast for his generous interest in all educational activities. The scheme made such a promising start that it was decided to try and bring in the pupils of the three other Mission schools in the town. To this end a small 'Bekwai Education Committee' was formed in 1942 including the scheme's benefactor and a repre- 
sentative from each of the schools. At this stage the Native Authority, the Bekwaihene and his Councillors, began to take an interest and, in addition to appointing two members to the Committee, voted a sum of $£ 72$ towards the expenses of the expanded scheme. It was not long before all schoolboys in Bekwai from Standard I to Standard VII were devoting one day a week to art and craft work. Early in 1943 it was found possible to erect suitable buildings on a more central site and Bekwai United Schools Arts and Crafts Centre came into being under the charge of one of Mr. Meyerowitz's former pupils. 'The Centre, although still in an experimental stage, has already attracted widespread interest, and local enthusiasm has been such that the Committee has had some difficulty in controlling what constantly tends to become a too rapid expansion. Among the crafts taught are traditional Ashanti weaving (a broad loom has just been introduced), basket-making, mat-weaving, wood-carving, brick-making, and pottery. Associated with the Achimotatrained Supervisor are four craft-instructors whose knowledge of their own craft it is hoped to enhance without sactificing that natural grace of design for which the West African traditional crafts are justly reputed.

This Centre is believed to be the only one of its kind in West Africa where the pupils of four different denominational schools are taught together. Its finances are controlled by the Education Committee and the member-schools have adjusted their individual time-tables to fit in with the scheme. At the end of 1943 the Committee and the Bekwai Native Authority each offered a bursary tenable at Achimota to a suitable pupil of the Centre who wished to be trained as an apprentice in one of the craft-industries.

In addition to directing this experiment, the Bekwai Education Committee has started a Domestic Science Centre for the schoolgirls in the town and has investigated various local educational problems. When it is appreciated that the Committee had no official standing whatsoever and relied for its effect entirely on the voluntary co-operation of the Native Authority and the representatives of four such divergent Christian denominations as Roman Catholic, Anglican, Methodist, and Seventh Day Adventist, its initial success is surely a happy augury for the future of education in Africa.

\section{A Musical Play for Africans}

IN Chief Above and Chief Below, Hugh Tracey, of Broadcast House, Durban, has written a musical play. based on an old Zulu legend discovered by K. E. Masinga when searching for material suitable for broadcasting. The legend is narrated in verse at the beginning of the play, and this story of the Chief's daughter who was lured to the underworld to become the bride of the Chief Below, and of the famine and sorrow which overwhelmed her land till she was found and brought back by her old nurse, and 'then all the people rejoiced and singing they ploughed their fields', will suggest to the European reader many parallels with the myth of Demeter and Persephone.

The text of the play, which is published by Shuter and Shooter, Pietermaritzburg, with six full-page illustrations by E. F. Watkins, is given in Zulu and in English. We propose to publish a review in the next issue of Africa.

\section{'Revue des Sciences Médicales, Pharmaceutiques et Vétérinaires de L'Afrique Frangaise Libre'}

THE medical, entomological, and veterinary services of the French Colonial territories in Africa have, since 1942, issued a Revue des Sciences Médicales, Pharmaceutiques et Veterinaires de l'Afrique Frangaise Libre, which is published by the Imprimerie du Gouvernement Général, Brazzaville. The papers in the first two volumes cover a wide field, including clinical reports on some noteworthy medical cases and more general surveys of medical conditions in various territories. Among the latter is a regional account of the methods and 